\title{
Exenatide improves $\beta$-cell function up to 3 years of treatment in patients with type 2 diabetes: a randomised controlled trial
}

\author{
Daniël H van Raalte ${ }^{1, *}$, Mathijs C Bunck ${ }^{1,2, *}$, Mark M Smits ${ }^{1}$, T Hoekstra ${ }^{3,4}$, \\ Anja Cornér ${ }^{5}$, Michaela Diamant ${ }^{1,+}$, Bjorn Eliasson ${ }^{6}$, Marja-RiittaTaskinen $^{5}$, \\ Robert J Heine ${ }^{1,7}$, Ulf Smith ${ }^{6}$, HanneleYki-Järvinen ${ }^{5}$ and Andrea Mari ${ }^{8}$ \\ 'Diabetes Center, Department of Internal Medicine, VU University Medical Center, Amsterdam, \\ The Netherlands, ${ }^{2}$ Eli Lilly and Company, Utrecht, The Netherlands, ${ }^{3}$ Department of Health Sciences \\ and the EMGO Institute for Health and Care Research, VU University Amsterdam, Amsterdam, \\ The Netherlands, ${ }^{4}$ Department of Epidemiology and Biostatistics, VU University Medical Center, \\ Amsterdam, The Netherlands, ${ }^{5}$ Research Programs' Unit, Diabetes and Obesity, University of Helsinki, \\ Helsinki, Finland, 'Lundberg Laboratory for Diabetes Research, Sahlgrenska University Hospital, \\ Göteborg, Sweden, ${ }^{7}$ Eli Lilly and Company, Indianapolis, Indiana, USA, and ${ }^{8}$ Institute of Neuroscience, \\ National Research Council, Padova, Italy \\ *(DH van Raalte and MC Bunck contributed equally to this work) \\ ${ }^{\dagger}$ (M Diamant is deceased)
}

\author{
Correspondence \\ should be addressed \\ to $\mathrm{D} \mathrm{H}$ van Raalte \\ Email \\ d.vanraalte@vumc.n
}

\begin{abstract}
Objective: Glucagon-like peptide (GLP)-1 receptor agonist treatment improves $\beta$-cell function. In this study, we investigated whether the improvements are sustained during a 3-year treatment period.

Research design and methods: Sixty-nine metformin-treated type 2 diabetes patients were randomised to the GLP1 receptor agonist, exenatide (EXE) twice daily (BID) or to insulin glargine (GLAR). $\beta$-cell function parameters were derived using the Mari model from standardised breakfast and lunch meals that were administered before treatment, and after 1 and 3 years of treatment. EXE was administered before breakfast.

Results: Fifty-nine (EXE: $n=30$; GLAR: $n=29$ ) and thirty-six (EXE: $n=16$; GLAR: $n=20$ ) patients completed the meal at 1- and 3-year treatment respectively. After 3 years, groups had comparable glycaemic control (HbA1c: EXE 6.6 $\pm 0.2 \%$ and GLAR $6.9 \pm 0.2 \% ; P=0.216)$. Compared with GLAR, at 1 and 3 years, EXE induced a stronger reduction in post-breakfast glucose concentrations $(P<0.001)$, with lower $C$-peptide levels $(P<0.001)$. Compared with GLAR, EXE increased insulin secretion at $8 \mathrm{mmol} / \mathrm{L}$ glucose throughout the study period $(P<0.01)$. Both treatments improved $\beta$-cell glucose sensitivity after 1-year treatment. However, only EXE treatment sustained this improvement for 3 years. No consistent changes in other $\beta$-cell parameters including rate sensitivity and potentiation were observed.

Conclusions: Compared with GLAR, EXE improved the parameters of $\beta$-cell function, especially insulin secretion at $8 \mathrm{mmol} / \mathrm{L}$ glucose and $\beta$-cell glucose sensitivity, which was sustained during the 3-year treatment period.

European Journal of

Endocrinology

(2016) 175, 345-352
\end{abstract}

\section{Introduction}

Type 2 diabetes (T2D) is characterised by defects in both insulin sensitivity and insulin secretion (1). The progressive loss of $\beta$-cell function over time results in a need for glucose-lowering agents, eventually resulting in the need for insulin replacement therapy in many patients

(c) 2016 European Society of Endocrinology Printed in Great Britain
$(2,3,4)$. Therapies that can preserve $\beta$-cell function in $\mathrm{T} 2 \mathrm{D}$ are required.

In the last decade, glucagon-like peptide-1 (GLP1) receptor agonists have been introduced for the treatment of T2D. GLP1 receptor agonists mainly lower blood glucose

Published by Bioscientifica Ltd. 
levels by inhibiting gastric emptying (postprandial), increasing insulin secretion and decreasing glucagon secretion, in a glucose-dependent manner $(5,6)$. Although in a number of rodent models, GLP1 receptor agonist treatment durably improved $\beta$-cell function, and also increased $\beta$-cell mass (7), there is no evidence for increased functional $\beta$-cell mass following GLP1 receptor agonist treatment in humans $(8,9)$. The extent to which the improvement in $\beta$-cell function by GLP1 receptor agonists is sustained over time (i.e. during treatment) is unclear due to the scarcity of longterm studies using dynamic tests of $\beta$-cell function. In trials of duration longer than 1 year, $\beta$-cell function was estimated in the fasting state using surrogate indices $(10,11)$, which provides only a limited reflection of $\beta$-cell function.

Earlier we reported that 1 month following cessation of therapy, 3-year treatment with the GLP1 receptor agonist exenatide (EXE), compared with insulin glargine (GLAR), induced a small improvement in the disposition index, which was calculated by multiplying 1st phase C-peptide secretion (derived from hyperglycaemic clamp) and insulin sensitivity (obtained by hyperinsulinaemic-euglycaemic clamp) (8). The improved disposition index was driven by an increment in insulin sensitivity, while C-peptide secretion was unchanged as compared with baseline after treatment cessation. This modest improvement in $\beta$-cell defect, however, did not result in better glycaemic control.

In this study, we report the effects of EXE twice daily (BID), as compared with GLAR, on meal-stimulated $\beta$-cell function parameters during 1-3years of treatment. The meal-related response provides different aspects of $\beta$-cell function, including $\beta$-cell glucose sensitivity, which are generated under more physiological conditions, i.e. in the postprandial state. In this state, the GLP1 receptor agonist EXE also induces effects beyond the $\beta$-cell, including inhibition of gastric emptying, reduction of glucagon levels and endogenous glucose production (EGP) (12). In this study, in contrast to the previous publication, the patients were undergoing treatment during the $\beta$-cell function analyses.

\section{Research design and methods}

Details on the study design were reported previously $(5,8)$. Briefly, 69 patients were randomised (using a permuted block randomisation scheme stratified by site and baseline HbA1c stratum $(\leq 8.5 \%$ or $>8.5 \%)$ ) at the three study sites in Finland, Sweden and the Netherlands.

Patients randomised to EXE initiated treatment at a dose of $5 \mu \mathrm{g}$ twice daily (BID) for a period of 4 weeks, followed by a dose increase to $10 \mu \mathrm{g}$ BID. EXE was titrated to a maximum dose of three times (TID) $20 \mu \mathrm{g}$, or the maximum tolerated dose, when $\mathrm{HbA1c}$ value at two consecutive visits ranged between 7.1 and $7.5 \%$, or when HbA1c was $>7.6 \%$ at any given visit. Patients randomised to GLAR started with an initial dosage of $10 \mathrm{IU}$ once daily (QD) at bedtime, followed by self-adjustment of the daily dose according to a fixed-dose treat-to-target (fasting plasma glucose (FPG) $<5.6 \mathrm{mmol} / \mathrm{L}$ )) algorithm, as described previously (13). Loss of glucose control was defined by fasting blood glucose concentrations greater than or equal to $12.2 \mathrm{mmol} / \mathrm{L}$ for 4 or more days out of 7 days during the study, with the increase in glucose concentrations not secondary to a readily identified inter-current illness or pharmacological treatment. The study protocol was approved by each site's ethics review committee and was conducted in accordance with the principles described in the Declaration of Helsinki. Patients were recruited at the local sites through advertising. All participating patients gave their written informed consent before screening. This study is registered with ClinicalTrials.gov under number NCT00097500.

\section{Standardised mixed-meal test}

Patients arrived at the study centre after an overnight fast. We placed a cannula into the non-dominant dorsal hand or wrist vein and maintained in a heated box at $50^{\circ} \mathrm{C}$ for blood collections. Two sequential mixed-meal tests were performed before randomisation, and after 1 and 3 years of treatment. At each meal visit, subjects received two standardised high-fat mixed meals: one at breakfast $(08: 30 \mathrm{~h})$ and one at lunchtime $(12: 30 \mathrm{~h})$. Each meal consisted of $50 \mathrm{~g}$ fat, $75 \mathrm{~g}$ carbohydrates and $35 \mathrm{~g}$ protein to provide a strong secretory stimulus for the $\beta$-cell. The breakfast consisted of an Egg McMuffin (McDonald's), croissant with butter, $200 \mathrm{~mL}$ semi-skimmed milk, combined with $20 \mathrm{~mL}$ cream. The lunch consisted of Quarter Pounder (McDonald's), croissant with butter and $200 \mathrm{~mL}$ semi-skimmed milk. Subjects were instructed to consume each meal within $15 \mathrm{~min}$. Blood samples for determination of glucose, insulin and C-peptide were collected at times minus $15,0,10,15,20,30,45,60,90$, $120,150,180,210,240,250,255,260,270,285,300$, $330,360,420$ and $480 \mathrm{~min}$. During the meal tests at year 1 and 3, patients received their study medication at the protocol-specified time, which was chosen according to the current prescription guidelines. Patients randomised to EXE were given the study drug 15 min before breakfast 
(no EXE was given before the lunch meal) and patients randomised to GLAR received their last insulin dose the previous night before bedtime.

\section{Laboratory analyses}

Plasma glucose concentrations were measured at bedside using an YSI 2300 STAT PLUS (Yellow Springs Instruments, Yellow Springs, OH, USA) in Sweden and the Netherlands, and using a Beckman Coulter Glucose Analyzer II (Beckman Coulter, Fullerton, CA, USA) in Finland. Serum was separated by centrifugation (1300-1500 g) and stored at $-80^{\circ} \mathrm{C}$ until analysis. Insulin and C-peptide samples were analysed at the VU University Medical Center using an immunoradiometric assay (Centaur; Bayer Diagnostics, Mijdrecht, The Netherlands). Intra-assay and inter-assay coefficient of variation for insulin were 4 and $7 \%$ and for C-peptide 5 and 8\% respectively. HbA1C (normal range: 4.3-6.1\%, DCCT standardised Bio-Rad assay), FPG and serum safety parameters were measured by a central laboratory (Quintiles International, Livingston, UK).

\section{Calculations}

Incremental area under the 4-h postprandial curves (iAUCs) for glucose, insulin and C-peptide curves was determined by using the trapezoidal rule. iAUCs for breakfast and lunch were calculated separately. Insulin sensitivity was estimated using the OGIS index (14).

\section{$\beta$-cell function model}

$\beta$-cell function was assessed from the meal test using a model describing the relationship between insulin secretion (ISR, expressed in $\mathrm{pmol} \cdot \mathrm{min}^{-1} \mathrm{~m}^{-2}$ ) and glucose concentration as the sum of two components $(15,16)$. The first component represents the dependence of ISR on glucose concentration through a dose-response function relating the two variables. From the dose-response, $\beta$-cell glucose sensitivity (the slope) and ISR at a fixed glucose concentration of $8 \mathrm{mmol} / \mathrm{L}$ (approximately the mean fasting glucose concentration in the groups before treatment) were calculated. The dose-response was modulated by a potentiation factor accounting for various mechanisms (prolonged hyperglycaemia, nonglucose substrates, gastro-intestinal hormones, neural modulation and drug effects) (17). The potentiation factor averaged one during the test and expressed relative potentiation or inhibition of ISR; its excursion was quantified by the ratio between the 3 -h and the baseline value (potentiation ratio). The second ISR component represents the dependence of ISR on the rate of change of glucose concentration and is determined by a single parameter (rate sensitivity) related to early insulin release (17). The model parameters were estimated from glucose and C-peptide concentrations (using C-peptide deconvolution) as described previously $(15,16)$. Estimation of the individual model parameters was performed by an investigator who was blinded to the randomisation status of patients.

\section{Statistical analysis}

Baseline characteristics and end-point measurements are presented as mean \pm S.E.M. Linear mixed models were used to assess within- and between-group treatment effects. The dependent variable used in the model was the outcome of interest (i.e. $\beta$-cell function parameters and fasting glucose/insulin). For withingroup effects, time was included as fixed factor, and analyses were performed separately for the EXE and GLAR groups. For between-group effects, treatment and time were included as the fixed factors. The effect of interest was the intervention-time interaction, which displays the effect of intervention at each time point (year 1 and 3), corrected for pretreatment values. The statistical models included factors for study site (the Netherlands/Sweden/Finland), baseline HbA1c stratum $(\leq 8.5 \% />8.5 \%)$ and body weight. Models were checked for meeting test assumptions, and where necessary, adjustments were made. Correlations between $\beta$-cell parameters and HbA1c were performed using Pearson's test. All analyses were performed using SPSS 22.0 (IBM SPSS). All inferential statistical tests were conducted at a significance level of 0.05 (two-sided).

\section{Results}

\section{Clinical characteristics}

Patients' characteristics are given in Table 1, which have been published previously $(5,8)$. No differences were observed between the groups at baseline. Fifty-nine patients (EXE: $n=30$; GLAR: $n=29$ ) completed both the pre-treatment and 1-year meal test. Thirty-six patients (EXE: $n=16$; GLAR: $n=20$ ) participated in the 3-year meal test (Supplementary Fig. 1, see section on supplementary data given at the end of this article). 
Table 1 Anthropometrics and metabolic variables. Data are presented as mean \pm S.E.M.

\begin{tabular}{|c|c|c|c|c|c|}
\hline & Baseline & Year 1 & Year 3 & $P$ value 1 & $P$ value 2 \\
\hline \multicolumn{6}{|l|}{$n$} \\
\hline EXE & 36 & 30 & 16 & - & - \\
\hline GLAR & 33 & 29 & 20 & - & - \\
\hline \multicolumn{6}{|l|}{ Age (years) } \\
\hline EXE & $58 \pm 1$ & - & - & - & - \\
\hline GLAR & $58 \pm 1$ & - & - & - & - \\
\hline \multicolumn{6}{|l|}{ Male sex $(\%)$} \\
\hline EXE & 64 & 60 & 69 & - & - \\
\hline GLAR & 67 & 73 & 70 & - & - \\
\hline Weight (kg) & & & & $<0.001$ & $<0.001$ \\
\hline EXE & $90.6 \pm 2.1$ & $86.2 \pm 2.6$ & $85.9 \pm 2.8$ & & \\
\hline GLAR & $92.4 \pm 2.4$ & $94.4 \pm 2.5$ & $94.8 \pm 3.3$ & & \\
\hline BMI $\left(\mathrm{kg} / \mathrm{m}^{2}\right)$ & & & & $<0.001$ & $<0.001$ \\
\hline EXE & $30.9 \pm 0.7$ & $29.2 \pm 0.8$ & $28.7 \pm 1.0$ & & \\
\hline GLAR & $30.1 \pm 0.6$ & $30.5 \pm 0.8$ & $30.5 \pm 0.9$ & & \\
\hline \multicolumn{6}{|l|}{ Diabetes duration (years) } \\
\hline EXE & $5.7 \pm 0.8$ & - & - & - & - \\
\hline GLAR & $4.0 \pm 0.6$ & - & - & - & - \\
\hline \multicolumn{6}{|l|}{ Medication dosage } \\
\hline EXE ( $\mu \mathrm{g} /$ day $)$ & - & $29.5 \pm 3.0$ & $22.5 \pm 2.2$ & - & - \\
\hline GLAR (U/day) & - & $33.6 \pm 3.5$ & $33.7 \pm 4.0$ & - & - \\
\hline $\mathrm{HbA} 1 \mathrm{c}(\%)$ & & & & 0.919 & 0.216 \\
\hline EXE & $7.6 \pm 0.1$ & $6.8 \pm 0.1$ & $6.6 \pm 0.2$ & & \\
\hline GLAR & $7.4 \pm 0.1$ & $6.7 \pm 0.1$ & $6.9 \pm 0.1$ & & \\
\hline Fasting glucose (mM) & & & & $<0.001$ & $<0.001$ \\
\hline EXE & $9.4 \pm 0.4$ & $7.2 \pm 0.3$ & $7.0 \pm 0.3$ & & \\
\hline GLAR & $8.9 \pm 0.4$ & $5.4 \pm 0.2$ & $5.7 \pm 0.2$ & & \\
\hline Fasting insulin (pM) & & & & $<0.001$ & $<0.001$ \\
\hline EXE & $87 \pm 12$ & $79 \pm 8$ & $76 \pm 8$ & & \\
\hline GLAR & $76 \pm 12$ & $151 \pm 13$ & $187 \pm 26$ & & \\
\hline Fasting C-peptide (nM) & & & & $<0.001$ & $<0.001$ \\
\hline EXE & $0.9 \pm 0.1$ & $0.8 \pm 0.1$ & $0.8 \pm 0.1$ & & \\
\hline GLAR & $0.8 \pm 0.1$ & $0.6 \pm 0.1$ & $0.6 \pm 0.1$ & & \\
\hline OGIS (mL/min $\left.\mathrm{m}^{2}\right)$ & & & & 0.775 & 0.830 \\
\hline EXE & $240 \pm 9$ & $337 \pm 15$ & $351 \pm 20$ & & \\
\hline GLAR & $249 \pm 7$ & $352 \pm 11$ & $362 \pm 15$ & & \\
\hline
\end{tabular}

OGIS, oral glucose insulin sensitivity. $P$ value 1 denotes EXE vs GLAR year-1 data; $P$ value 2 denotes EXE vs GLAR year-3 data.

The majority (69\%) of patients treated with EXE was treated with a dose of $10 \mu \mathrm{g}$ BID (average dosage provided in Table 1). At 1 and 3 years of treatment, the mean \pm s.E.M. GLAR dosages used were $33.6 \pm 3.5$ and $33.7 \pm 4.0$ units per day respectively. The reduction in HbA1c was similar between the groups at both year 1 and year 3, while fasting glucose levels were lower in the GLAR group (Table 1) (8). EXE significantly reduced body weight compared with GLAR, with the mean weight difference $7.4 \pm 1.4 \mathrm{~kg}$ at 3 years $(P<0.001)(8)$. The data of the participants who completed the entire study protocol are provided Supplementary Table 1.

\section{Postprandial profiles}

After 1 and 3 years of treatment, EXE induced a strong reduction in postprandial glucose levels following breakfast $(P<0.001)$ compared with baseline (Figs 1A and 2A). By contrast, GLAR treatment had no effect on post-breakfast incremental glucose after 1 year, while glucose excursions increased after 3 years $(P<0.001$; Figs $1 \mathrm{~B}$ and $2 \mathrm{~A})$. EXE was associated with lower post-breakfast glucose levels than GLAR after 1 and 3 years of treatment (both $P<0.001$; Fig. 2A). No differences were seen after the lunch meal between the groups, where the glucose excursions were higher following treatment with either EXE or GLAR (Figs 1A, B and 2B) than that after breakfast. During the 8-hour meal test, EXE reduced postprandial glucose levels significantly, both compared with GLAR and baseline $(P<0.001)$ (Fig. 2C). EXE reduced the glucose concentrations after breakfast, in addition to reducing insulin and C-peptide levels (Figs 1C, E and 2D, G). GLAR did 
A

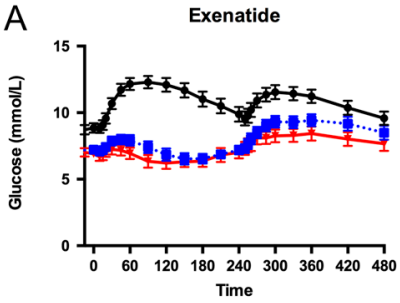

C

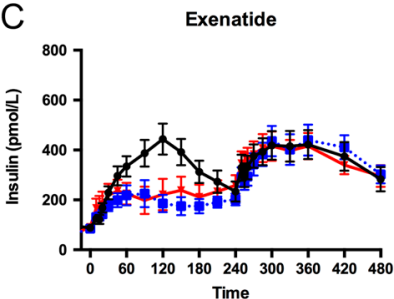

$E$

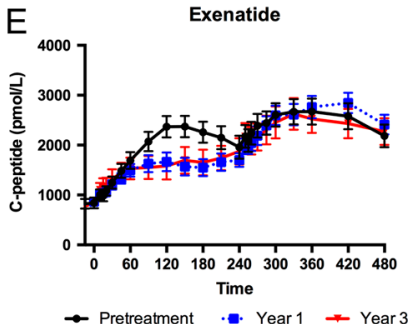

B

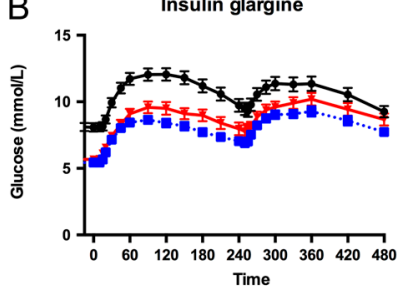

D
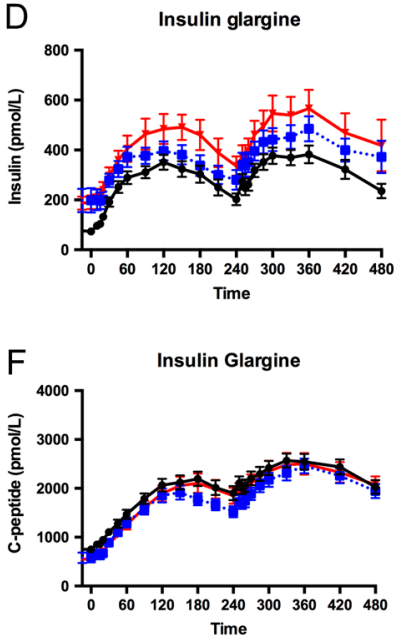

Figure 1

Postprandial curves for glucose, insulin and C-peptide for exenatide (panels A, C and E) and insulin glargine (panels B, D and F).

not consistently alter postprandial insulin or C-peptide concentrations (Figs 1D, F and 2D, E, F, G, H, I).

\section{$\beta$-cell function measures}

EXE improved the insulin secretion at $8 \mathrm{mmol} / \mathrm{L}$ glucose compared with GLAR during the 3-year treatment period $(P<0.001)$ (Fig. 3A). Compared with baseline values, EXE increased glucose sensitivity, which was sustained throughout the 3-year period (year 1 vs baseline: $15.0 \pm 6.7 \mathrm{pmol} / \mathrm{min} . \mathrm{m}^{2} . \mathrm{mM} ; P<0.05$; year 3 vs baseline: $\left.21.6 \pm 8.4 \mathrm{pmol} / \mathrm{min} \cdot \mathrm{m}^{2} . \mathrm{mM} ; \quad P<0.01\right)$. Meanwhile the initial increase seen with GLAR (year 1 vs baseline: $21.4 \pm 6.9 \mathrm{pmol} / \mathrm{min} . \mathrm{m}^{2} . \mathrm{mM} ; P<0.01$ ) was not present after 3 years of treatment (year 3 vs baseline: $2.1 \pm 7.8 \mathrm{pmol} / \mathrm{min}$. $\left.\mathrm{m}^{2} . \mathrm{mM} ; \mathrm{P}=0.794\right)$. At 3 years of treatment, the betweengroup difference in $\beta$-cell glucose sensitivity showed a trend towards significance in favour of EXE (difference $17.9 \pm 3.5 \mathrm{pmol} / \mathrm{min} \cdot \mathrm{m}^{2} \cdot \mathrm{mM} ; P=0.06$ ) (Fig. $3 \mathrm{~B}$ ). At year 1 , rate sensitivity increased more with GLAR compared with EXE, an effect that disappeared at 3 years of treatment (Fig. 3C). No differences were seen with regard to potentiation between the groups (Fig. 3D). At year 3, the insulin secretion at $8 \mathrm{mmol} / \mathrm{L}$ glucose $(r=-0.649 ; P=0.007)$ and glucose sensitivity $(r=-0.678 ; P=0.004)$ were inversely correlated with $\mathrm{HbA1c}$ in the EXE-treated individuals, but not in the GLAR-treated group ( $r=0.292$ and $r=-0.045$ respectively; $P=$ ns for both).

\section{Safety and tolerability}

The safety data of this study have been discussed in detail previously (8). In general, the study medication
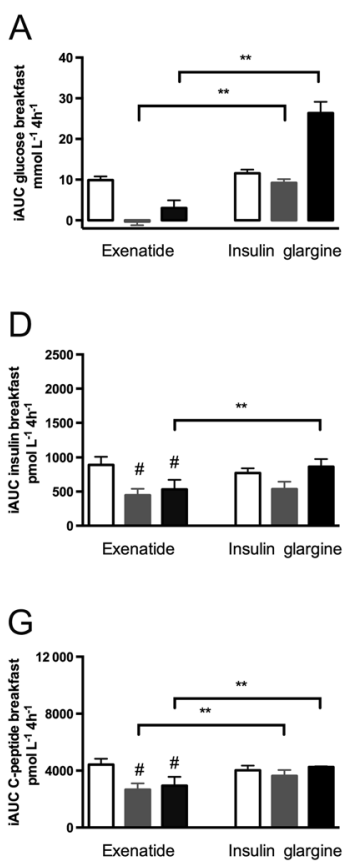

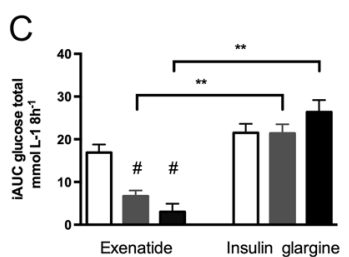

E

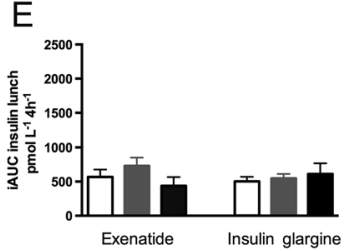

$\mathrm{H}$

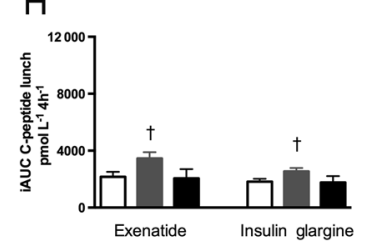

$\mathrm{F}$
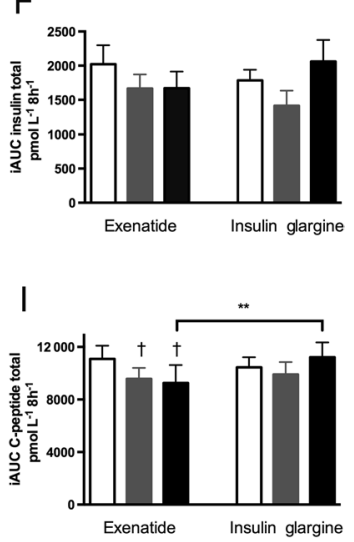

Figure 2

Incremental area under the curve (iAUC) for glucose (panels $A, B$ and $C$ ), insulin (panels D, E and F) and C-peptide (G, H and I) at baseline and after 1- and 3-year treatment with exenatide or insulin glargine. iAUC are shown for breakfast, lunch and for the total test day. Symbols: ${ }^{*} P<0.01, * P<0.05$ for between-group comparisons. ${ }^{\#} P<0.01, \stackrel{ }{*} P<0.05$ for within-group comparisons. 
A

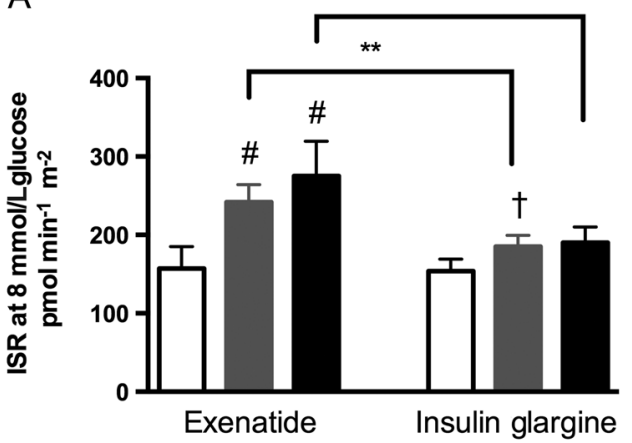

B
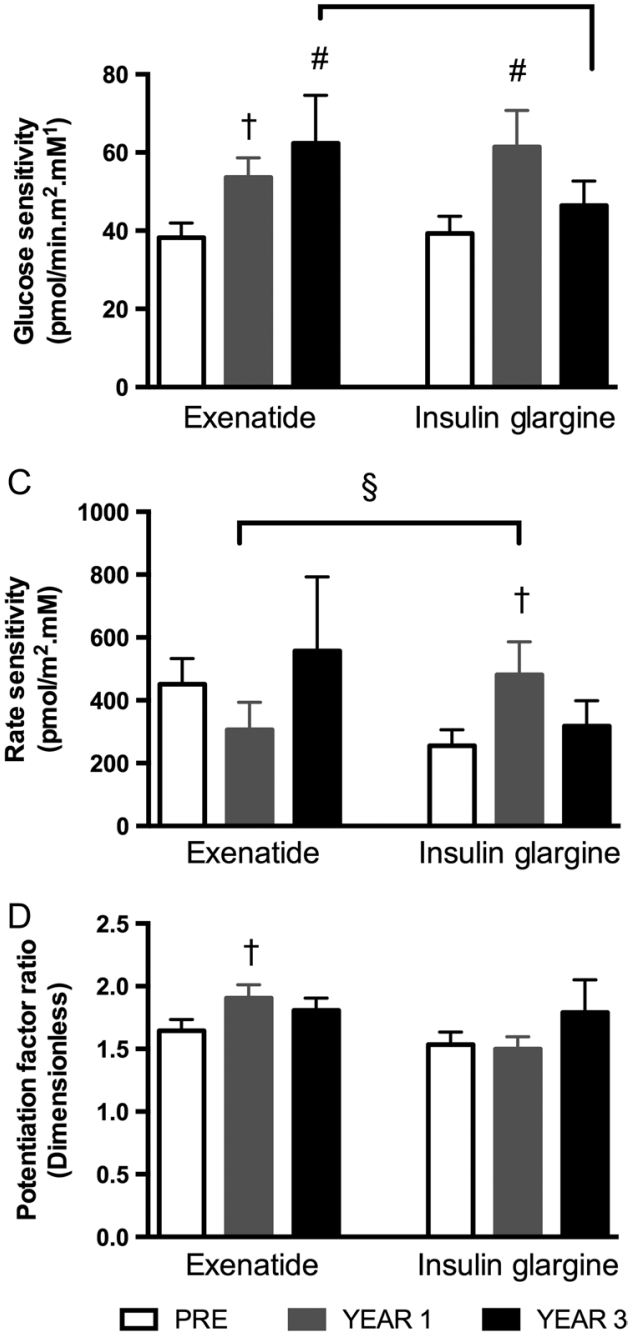

Figure 3

The effects of 1 and 3 years of treatment with exenatide (EXE) or insulin glargine (GLAR) on parameters of $\beta$-cell function (panel A: secretion at $8 \mathrm{mmol} / \mathrm{L}$ glucose; panel B: glucose sensitivity; panel C: rate sensitivity; panel D: potentiation). Symbols: ${ }^{*} P<0.01,{ }^{\S} P=0.051, \mathbb{I} P=0.06$ for between-group comparisons. ${ }^{\#} P<0.01,{ }^{\dagger} P<0.05$ for within-group comparisons. was well tolerated. The most common adverse events of EXE included gastrointestinal complaints (42.9\%), mostly mild-to-moderate nausea. Most commonly reported adverse event associated with GLAR treatment was minor hypoglycaemia. No major hypoglycaemia was observed in this study.

\section{Discussion}

In this study, we show that EXE, a short-acting GLP1 receptor agonist, compared with GLARG, improves $\beta$-cell glucose sensitivity and insulin secretion at $8 \mathrm{mmol} / \mathrm{L}$ glucose, for up to 3 years of treatment in similarly wellcontrolled metformin-treated type 2 diabetes patients, statistically independent of changes in body weight. The effects of EXE are thus sustained, concern multiple parameters derived during the postprandial state, and occur in face of an expected improvement in insulin sensitivity. This is a novel finding, as the prior 3-year study on this cohort assessed insulin secretion with the hyperglycaemic clamp 1 month after cessation of therapy and did not observe a sustained improvement of insulin secretion by EXE treatment (8).

At year 1, GLAR treatment also improved the standardised insulin secretion rate at $8 \mathrm{mmol} / \mathrm{L}$ glucose, glucose sensitivity and rate sensitivity compared with baseline. This probably occurred because of lowering glucotoxicity and/or by inducing $\beta$-cell rest. Compared with EXE, the improvement in rate sensitivity reached borderline significance. However, none of these effects was sustained at year 3, while glycaemic control remained similar. At year 1, EXE improved insulin secretion at $8 \mathrm{mmol} / \mathrm{L}$ glucose, glucose sensitivity and potentiation compared with baseline, confirming data from previous short-term studies using GLP1 receptor agonists $(18,19)$. The difference in insulin secretion at $8 \mathrm{mmol} / \mathrm{L}$ glucose was significantly different compared with GLAR. In contrast to GLAR, the improvement in insulin secretion at $8 \mathrm{mmol} / \mathrm{L}$ glucose and glucose sensitivity with EXE was sustained at year 3, indicating preserved $\beta$-cell responsiveness. Betweengroup changes at year 3 were significant for insulin secretion at $8 \mathrm{mmol} / \mathrm{L}$ glucose and reached borderline significance for glucose sensitivity. The significant inverse correlations of insulin secretion at $8 \mathrm{mmol} / \mathrm{L}$ glucose and glucose sensitivity after 3 years of EXE treatment with $\mathrm{HbA1c}$ demonstrate the importance of $\beta$-cell function in glycaemic control with GLP1 receptor agonist treatment. 
GLP1 receptor agonists have previously been shown to improve $\beta$-cell function in type 2 diabetic patients using both static and dynamic tests; the latter includes hyperglycaemic clamps $(5,20)$ and oral glucose or meal tolerance tests $(9,18,19)$. However, these studies were limited by the relatively short treatment duration (i.e. 1 year maximum). The importance of studies of longer duration is stressed by landmark trials such as the United Kingdom Prospective Diabetes Study (UKPDS) and A Diabetes Outcome Progression Trial (ADOPT), where initial treatment success was followed by rapid loss of glycaemic control due to $\beta$-cell failure associated with a number of drugs $(3,4)$.

Our long-term data are in line with the results from the open-label 3-year extension study of the EXE phase III programme. In the extension phase, EXE continued to improve homeostatic model assessment of $\beta$-cell function (HOMA-B), a static measure for $\beta$-cell function (11). However, this parameter provides very limited information regarding $\beta$-cell function compared with dynamic tests. Also, this parameter is more difficult to interpret when concomitant changes in insulin sensitivity occur, as is the case for EXE which increases insulin sensitivity, likely secondary to weight reduction (8).

Some studies in rodents have suggested that GLP1 may increase $\beta$-cell functional mass, resulting in improved glycaemic control even after cessation of therapy (7). However in humans, for EXE (8), liraglutide (9) and the dipeptidyl peptidase (DPP)-4 inhibitor vildagliptin (21), no such effects were observed. In fact, loss of glycaemic control occurred quickly after treatment discontinuation, despite a small improvement in disposition index by EXE treatment (8).

In this study, we show that the beneficial effects of EXE on $\beta$-cell function, along with HbA1c values, are sustained during treatment. Importantly, EXE was administered just before breakfast, as is usual for patients in the reallife setting. Therefore the effects observed during the breakfast meal tests are likely to be acute in nature, and show that there is no loss of efficacy over the 3-year period. The marked differences in postprandial glucose, insulin and C-peptide curves between the first and second meal further demonstrate the short-term effects of EXE.

The meal tests performed in this study confirm the postprandial profile of short-acting GLP1 receptor agonists. The profile is characterised by low postprandial glucose concentrations with concomitantly reduced insulin or C-peptide levels. The reduction in postprandial glucose levels, as was only seen in the breakfast meal in this study, in addition to improvement in $\beta$-cell function, is caused by reduced gastric emptying (22), glucagon secretion (6) and EGP (12). Due to the short duration of action of EXE, none of its effects was observed following the second meal. Similar observations have been shown for the other short-acting GLP1 receptor agonist lixisenatide and differ from long-acting GLP1 receptor agonists such as liraglutide (23).

A limitation of this study is the small number of patients who completed the entire protocol (44 and 61\% for EXE and GLAR respectively). It should be noted that this study was very demanding for patients with a total of 30 visits, including three euglycaemic-hyperglycaemic clamp procedures and three consecutive meal tests. This led to withdrawal of consent after the initial 1-year study. In both the EXE and GLAR arms, we found no statistical difference between the subjects who continued in the extension study compared with the patients who stopped after 1-year treatment, including treatmentinduced effects on weight, $\beta$-cell function and HbA1c. Nevertheless, we cannot exclude a certain selection bias. In addition, a number of patients were excluded to due to loss of glycaemic control, which occurred primarily during the obligatory off-drug period that was part of the protocol (8).

To conclude, EXE, compared with GLAR, improves meal-related $\beta$-cell function that is sustained during 3-year treatment period.

\section{Supplementary data}

This is linked to the online version of the paper at http://dx.doi.org/10.1530/ EJE-16-0286.

\section{Declaration of interest}

The study was collectively initiated and designed by the investigators from the study sites. The investigators had full access to the trial data and had control over the statistical analysis and interpretation of the study results. $\mathrm{M} \mathrm{CB}$ and $\mathrm{R} J \mathrm{H}$ are employees and stockholders of Eli Lilly and Co. During the study, M C B and R J H were employed at the VU University Medical Center. Before she passed away, M D was a consultant and speaker for Eli Lilly and Co. Through M D, the VU University Medical Center has received research grants from Amylin Pharmaceuticals, Inc., and Eli Lilly and Co. Through U S, the Sahlgrenska University Hospital has received research grants from Amylin Pharmaceuticals, Inc., and Eli Lilly and Co. H Y.-J serves as a consultant for Amylin Pharmaceuticals, Inc. Through H Y.-J, the Helsinki University Central Hospital has received research grants from Amylin Pharmaceuticals, Inc., and Eli Lilly and Co. B E is a consultant and speaker for Eli Lilly and Co. M-R T serves as a consultant for Novo Nordisk A/S. No other potential conflicts of interest relevant to this article are reported.

\section{Funding}

This study was sponsored by Amylin Pharmaceuticals Inc., now a wholly owned subsidiary of AstraZeneca, and Eli Lilly and Company. 


\section{Author contribution statement}

M C B, A C and B E conducted the study. R J H, M R T, U S, M D and $\mathrm{H} Y \mathrm{~J}$ designed the study. M M S, D V R and A M analysed the data and performed statistical analyses. All authors contributed to the discussion. D V R and A M wrote the manuscript. D H van Raalte is the guarantor of this work.

\section{Acknowledgements}

The study was collectively initiated and designed by the investigators from the study sites. The investigators had full access to the trial data and had control over the statistical analyses and interpretation of the study results.

\section{References}

1 Defronzo RA. Banting lecture. From the triumvirate to the ominous octet: a new paradigm for the treatment of type 2 diabetes mellitus. Diabetes 200958 773-795. (doi:10.2337/db09-9028)

2 Heine RJ, Diamant M, Mbanya JC \& Nathan DM. Management of hyperglycaemia in type 2 diabetes: the end of recurrent failure? BMJ 2006333 1200-1204. (doi:10.1136/bmj.39022.462546.80)

3 Kahn SE, Haffner SM, Heise MA, Herman WH, Holman RR, Jones NP, Kravitz BG, Yu D, Heise MA, Aftring RP et al. Glycemic durability of rosiglitazone, metformin, or glyburide monotherapy. New England Journal of Medicine 2006355 2427-2443. (doi:10.1056/NEJMoa066224)

4 U.K. prospective diabetes study 16 . Overview of 6 years' therapy of type II diabetes: a progressive disease. U.K. Prospective Diabetes Study Group. Diabetes 199544 1249-1258. (doi:10.2337/diabetes.44.11.1249)

5 Bunck MC, Diamant M, Corner A, Eliasson B, Malloy JL, Shaginian RM, Deng W, Kendall DM, Taskinen MR, Smith U et al. One-year treatment with exenatide improves beta-cell function, compared with insulin glargine, in metformin-treated type 2 diabetic patients: a randomized, controlled trial. Diabetes Care 200932 762-768. (doi:10.2337/dc08-1797)

6 Smits MM, Bunck MC, Diamant M, Corner A, Eliasson B, Heine RJ, Smith U, Yki-Jarvinen H \& van Raalte DH. Effect of 3 years of treatment with exenatide on postprandial glucagon levels. Diabetes Care 201639 e42-e43. (doi:10.2337/dc15-2489)

7 Wajchenberg BL. Beta-cell failure in diabetes and preservation by clinical treatment. Endocrine Reviews 200728 187-218. (doi:10.1210/10.1210/er.2006-0038)

8 Bunck MC, Corner A, Eliasson B, Heine RJ, Shaginian RM, Taskinen MR, Smith U, Yki-Jarvinen H \& Diamant M. Effects of exenatide on measures of beta-cell function after 3 years in metformin-treated patients with type 2 diabetes. Diabetes Care 2011 34 2041-2047. (doi:10.2337/dc11-0291)

9 Retnakaran R, Kramer CK, Choi H, Swaminathan B \& Zinman B. Liraglutide and the preservation of pancreatic beta-cell function in early type 2 diabetes: the LIBRA trial. Diabetes Care 201437 3270-3278. (doi:10.2337/dc14-0893)

10 Buse JB, Klonoff DC, Nielsen LL, Guan X, Bowlus CL, Holcombe JH, Maggs DG \& Wintle ME. Metabolic effects of two years of exenatide treatment on diabetes, obesity, and hepatic biomarkers in patients with type 2 diabetes: an interim analysis of data from the open-label, uncontrolled extension of three double-blind, placebo-controlled trials. Clinical Therapeutics 200729 139-153. (doi:10.1016/j. clinthera.2007.01.015)

11 Klonoff DC, Buse JB, Nielsen LL, Guan X, Bowlus CL, Holcombe JH, Wintle ME \& Maggs DG. Exenatide effects on diabetes, obesity, cardiovascular risk factors and hepatic biomarkers in patients with type 2 diabetes treated for at least 3 years. Current Medical Research and Opinion 200824 275-286. (doi:10.1185/030079908X253870)

12 Cervera A, Wajcberg E, Sriwijitkamol A, Fernandez M, Zuo P, Triplitt C, Musi N, DeFronzo RA \& Cersosimo E. Mechanism of action of exenatide to reduce postprandial hyperglycemia in type 2 diabetes. American Journal of Physiology Endocrinology and Metabolism 2008294 E846-E852. (doi:10.1152/ajpendo.00030.2008)

13 Yki-Jarvinen H, Juurinen L, Alvarsson M, Bystedt T, Caldwell I, Davies M, Lahdenpera S, Nijpels G \& Vahatalo M. Initiate insulin by aggressive titration and education (INITIATE): a randomized study to compare initiation of insulin combination therapy in type 2 diabetic patients individually and in groups. Diabetes Care $2007 \mathbf{3 0}$ 1364-1369. (doi:10.2337/dc06-1357)

14 Mari A, Pacini G, Murphy E, Ludvik B \& Nolan JJ. A model-based method for assessing insulin sensitivity from the oral glucose tolerance test. Diabetes Care 200124 539-548. (doi:10.2337/ diacare.24.3.539)

15 Mari A, Tura A, Gastaldelli A \& Ferrannini E. Assessing insulin secretion by modeling in multiple-meal tests: role of potentiation. Diabetes 200251 (Supplement 1) S221-S226. (doi:10.2337/ diabetes.51.2007.s221)

16 Mari A, Schmitz O, Gastaldelli A, Oestergaard T, Nyholm B \& Ferrannini E. Meal and oral glucose tests for assessment of beta -cell function: modeling analysis in normal subjects. American Journal of Physiology Endocrinology and Metabolism 2002283 E1159-E1166. (doi:10.1152/ajpendo.00093.2002)

17 Mari A \& Ferrannini E. $\beta$-cell function assessment from modelling of oral tests: an effective approach. Diabetes, Obesity \& Metabolism 2008 10 (Supplement 4) 77-87. (doi:10.1111/j.1463-1326.2008.00946.x)

18 Mari A, Degn K, Brock B, Rungby J, Ferrannini E \& Schmitz O. Effects of the long-acting human glucagon-like peptide-1 analog liraglutide on beta-cell function in normal living conditions. Diabetes Care 2007 30 2032-2033. (doi:10.2337/dc07-0310)

19 Mari A, Nielsen LL, Nanayakkara N, DeFronzo RA, Ferrannini E \& Halseth A. Mathematical modeling shows exenatide improved betacell function in patients with type 2 diabetes treated with metformin or metformin and a sulfonylurea. Hormone and Metabolic Research 200638 838-844. (doi:10.1055/s-2006-956505)

20 Vilsboll T, Brock B, Perrild H, Levin K, Lervang HH, Kolendorf K, Krarup T, Schmitz O, Zdravkovic M, Le-Thi T et al. Liraglutide, a oncedaily human GLP-1 analogue, improves pancreatic B-cell function and arginine-stimulated insulin secretion during hyperglycaemia in patients with type 2 diabetes mellitus. Diabetic Medicine 200825 152-156. (doi:10.1111/j.1464-5491.2007.02333.x)

21 Foley JE, Bunck MC, Moller-Goede DL, Poelma M, Nijpels G, Eekhoff EM, Schweizer A, Heine RJ \& Diamant M. Beta cell function following 1 year vildagliptin or placebo treatment and after 12 week washout in drug-naive patients with type 2 diabetes and mild hyperglycaemia: a randomised controlled trial. Diabetologia 201154 1985-1991. (doi:10.1007/s00125-011-2167-8)

22 Linnebjerg H, Park S, Kothare PA, Trautmann ME, Mace K, Fineman M, Wilding I, Nauck M \& Horowitz M. Effect of exenatide on gastric emptying and relationship to postprandial glycemia in type 2 diabetes. Regulatory Peptides 2008151 123-129. (doi:10.1016/j. regpep.2008.07.003)

23 Meier JJ, Rosenstock J, Hincelin-Mery A, Roy-Duval C, Delfolie A, Coester HV, Menge BA, Forst T \& Kapitza C. Contrasting effects of lixisenatide and liraglutide on postprandial glycemic control, gastric emptying, and safety parameters in patients with type 2 diabetes on optimized insulin glargine with or without metformin: a randomized, open-label trial. Diabetes Care 201538 1263-1273. (doi:10.2337/dc14-1984)

Received 30 March 2016

Revised version received 15 June 2016

Accepted 15 July 2016 